\title{
Pelaksanaan Teori Belajar Bermakna David Ausubel Dalam Pembelajaran Pendidikan Agama Islam
}

\author{
Hidayatul Muamanah \\ hidaidris28@gmail.com \\ Universitas Islam Negeri (UIN) Sunan Kalijaga \\ Suyadi \\ suyadi@uin-suka.ac.id \\ Universitas Islam Negeri (UIN) Sunan Kalijaga
}

\begin{abstract}
Meaningful learning that was initiated by David Ausubel was a process of linking new information with relevant concepts in a person's cognitive structure. By meaningful learning the knowledge received will last long in students' memories. Meaningful learning can be used to teach various fields of educational studies including Islamic Religious Education. The purpose of this study is to find out how the implementation of meaningful learning in Lukman Hakim Integrated Islamic Elementary School and know what are the inhibiting and supporting factors of implementing meaningful learning. The research was conducted at the Lukman Hakim Integrated Islamic Elementary School, Bantul, Yogyakarta. Research Results Teachers have implemented meaningful learning with the principles of the steps listed, but there is a need for deepening so that maximum results are obtained. Supporting factors in the application of meaningful learning are, the curriculum applied in schools which is the 2013 curriculum and the PHI curriculum, teacher pedagogical competence and infrastructure. The contributing factor to the application of meaningful learning is that students do not have the same enthusiasm for learning so there are some students who are not active in learning
\end{abstract}

Keywords: Meaningful learning, implementation, Islamic Religious Education.

Abstrak: Belajar bermakna yang dicetuskan oleh David Ausubel merupakan suau proses dikaitkannya informasi-informasi yang baru dengan konsep-konsep yang relevan dalam struktur kognitif seseorang. Dengan belajar bermakna pengetahuan yang diterima akan bertahan lama

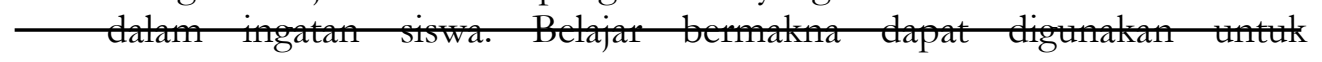

Belajea: Jurnal Pendidikan Islam Vol. 5, No 01, 2020; 23-36 p-ISSN 2548-3390; e-ISSN 2548-3404, DOI:10.29240/belajea.v5 available online at:http://journal.staincurup.ac.id/indek.php/belajea 
mengajarkan berbagai bidang studi pendidikan termasuk bidang studi Pendidikan Agama Islam. Tujuan penelitian ini adalah untuk mengetahui bagaimana pelaksanaan pembelajaran bermakna di Seklolah Dasar Islam Terpadu Lukman Hakim dan mengatahui apa yang menjadi faktor penghambat dan faktor pendukung dari pelaksanaan pembelajaran bermakna. Penitian dilakukan di Sekolah Dasar Islam Terpadu Lukman Hakim, Bantul Yogyakrta. elajaran bermakna dengan prinsip langkahlangkah yang tertera, namun perlu adanya pendalam lagi sehingga diperolah hasil yang maksimal. Faktor pendukung dalam penerapan pembelajaran bermakna adalah, kurikulum yang di terapkan di sekolah yang yakni K13 dan kurikulum Pendidikan Holistik Iintegratif (PHI), Kompetensi pedagogik guru dan sarana prasarana. Faktor penghabat penerapan pembelajaran bermakna adalah adalah siswa yang tidak memiliki semangat belajar yang sama sehingga ada beberapa siswa yang tidak aktif dala pmebelajaran.

Kata kunci : Pembelajaran bermakna, pelaksanaan, Pendidikan Agama Islam.

\section{Pendahuluan}

Mendapatkan pendidikan merupakan hak bagi setiap manusia. Pendidikan akan menjadikan manusia sempurna kehidupan dan penghidupannya dapat selaras dengan kodrat manusia lebih baik dari sebelumnya karena pendidikan akan membentuk watak sehingga menjadi manusia yang aktif dan kreatif. Pendidikan juga akan menjadikan individu dapat bersaing dengan berbagai orang dengan latar belakang negara yang bereda.

Pemerintah telah melakukan berbagai upaya untuk terus meningkatkan mutu pendidikan di negeri ini. Cara yang dilakukan oleh pemerintah yakni memberikan kebijakan dengan memberlakukan kurikulum yang diselaraskan dengan kondisi siswa, masyarakat sekitar siswa belajar dan sarana dan prasarana. ${ }^{1}$ Dalam pendidikan tentunya terdapat sebuah proses yang disebut dengan proese pembelajaran. Pembelajaran pada hakikatnya merupakan proses interaksi antara siswa dengan siswa, siswa dengan sumber belajar, dan siswa dengan pendidik. Pembelajaran akan bermakna jika diadakan di tempat dan lingkungan yang dapat

${ }^{1}$ I Wyn Sujana I Pt. Fira Kumartha, Md. Putra, "Bernuansa Lingkungan Alam Terhadap Hasil Belajar Ips Siswa Kelas Iv Sd Gugus 4 Selemadeg Timur Tabanan,” Portal Garuda, 2013. 
memberikan mensuport dengan baik dalam proses belajar. Pembelajaran merukan proses penting dan mempengaruhi antara guru dan siswa dalam hal ini proses yang berlangsung adalah guru mengajar dan siswa belajar. Menurut Mulyasa belajar dikatakan berhasil apabila peserta didik sama-sama, sebagian atau seluruhnya dapat aktif dalam proses pembelajaran baik fisik mental maupun sosial dalam proses belajar mengajar, disamping menunjukkan gairah semangat belajar yang tinggi, juga rasa percaya diri. Seorang dikatakan belajar apabila terdapat perubahan pada dirinya misalnya orang yang tidak bisa membaca kemudian dia belajar dan bisa membaca hal ini menunjukka bahwa teah terjadi proses belajar pada dirinya. Hal yang seruoa juga du ungkapkan oleh Gagne. Menurut Gagne balajar adalah suatu proses dimana suatu organisasi berubah prilakunya sebagai akbat dari pengalaman. ${ }^{2}$ Skinner mendefinisikan belajar yakni "Learning is a proccess of progresif behavior adaption" belajar merupakan suatu proses adaptasi prilaku yang bersifat progresif. ${ }^{3}$ Ini berarti bahwa adanya pengaruh ketika belajar maka menjadi lebih baik dari sebelumnya atau lebih sempurna dari sebelumnya.

Selain itu juga tidak kalah penting adalah peran seorang pendidik dalam mengembangan pola pikir peserta didiknya menjadi sorotan utama dalam rangka mewujudka pendidikan yang diidamkan oleh kita semua yakni pendidikan yang tidak hanya mencerdaskan akal namun juga bisa menanamkan perilaku yang baik. ${ }^{4}$ Perubahan prilaku yang terjadi pada siswa tersebut terjadi setelah adanya interaksi antara siswa dengan lingunkungan belajarnya itu disebut dengan balajar.

Untuk dapat mewujudkan pendidikan yang diidamkan terdapat dasar empiris harus dimiliki oleh seorang guru atau pendidik untuk mendukung mereka dalam melakukan tugas keprofesionalannya. ${ }^{5}$ Dasar itu salah satunya adalah teori belajar. Schellbecker mengatakan bahwa dirumuskannya teori ini tidak hanya penting namun juga diutamakan bagi ilmu psikologi dan ilmu 2006). hlm. 2

${ }^{2}$ Ratna Wilis Dahar, Teori-Teori Belajar Dan Pembelajaran (Bandung: Erlangga, hlm. 166.

${ }^{3}$ Bimo Walgito, Pengantar Psikologi Umum (Yogyakarta: ANDIOFFSET, 2004).

${ }^{4}$ Shoffan Shoffa, "Penerapan Strategi Meaningful Learning Dalam Meningkatkan Hasil Belajar Mahasiswa Pendidikan Matematika UM Surabaya Pada Mata Kuliah Pengantar Pendidikan," MUST: Journal of Mathematics Education, Science and Technology, 2016, https://doi.org/10.30651/must.v1i2.233.

5 Muhammad Thabrani dan Ali Mustofa, Belajar Dan Pembelajaran: Pengembangan Wacana Dan Praktik Pembelajaran Dalam Pembagunan Nasional (Yogyakarta: Ar-Ruzz Media, 2011). hlm 5. 
pendidikan agar dapat maju atau berkembang serta memecahkan problemproblem yang ditemukan dalam setiapa bidang itu. ${ }^{6}$ Karena tidak dapat dipungkiri masih banyak sekali permasalahan-permasalahan dalam proses pembelajaran salah satunya adalah pembelajaran Pendidikan Agama Islam.

Pendidikan Agama Islam merupakan mata pelajaran wajib yang harus diajarkan kepada peserta didik. Namun masih banyak dijumpai bahwa pendidikan agama islam belum mampu mencapai tujuan dari Pendidikan Agama Islam. Tujuan Pendidikan Agama Islama adalah menumbuhkan dan menigkatkan keimanan melalui pengetahuan, penghayatan, pengalaman, dan juga pengamalan atas pengetahuan yang ia peroleh sebagai wujud manusia yang beriman. ${ }^{7}$ Sehingga agar Pendidikan Agama Islam dapat mencapai tujuan maka diperukan metode pembelajaran yang dapat memberika makna bagi peserta didik sehingga tidak hanya Transfer pengeahuan namun juga namun juga transfer nilai. Tidak jarang dijumpai dalam pemebelajaran Pendidikan Agama Islam masih menggunakan metode atau strategi pembelajaran yang lama yang hanya menekankan pada pemahaman tanpa kebermaknaan. Hal ini sesuai dengan penapat S. A. Nasir yang dikutip oleh H. TB Aat Syafaat bahwa Pendidikan Agama Islam merupakan upaya untuk membimbing anak-anak dalam memahamai agamanya sehingga ajaran agam tersebut dapat menjiwai dalam diri anak-anak menjadi bagian terpenting bagi anak-anak yang dialkukan dengan sistematis. ${ }^{8}$ Sehingga sebagai pelajaran yang mengajarkan tentang norma atau aturan tentang agama dalam hidup manusia sebaiknya Pendidikan Agama Islam dapat diajarka dengan metode yang sama seperti mata pelajaran yang lain salah satunyA yaitu belajar yang mengedepankan kebermaknaan dan siswa dapat aktif dalam pelajaran Penidikan Agama Islam.

David Ausubel seorang ahli psikologi pendidikan yang terkenal mencetuskan sebuah teori yang dikenal dengan belajar bermakna (meaningful learning). ${ }^{9}$ Itskarisma dan Mawardi mengutip pendapat Yogihati bahwa belajar bermakna adalah "was an approach in managing the learning system through active learning methods towards independent learning. The ability to learn independently was the ultimate goal

\footnotetext{
${ }^{6}$ Dahar, Teori-Teori Belajar Dan Pembelajaran. hlm.

${ }^{7}$ Abdul Majid, Belajar Dan Pembelajaran :Pendidikan Agama Islam (Bandung: Remaja Rosdakarya, 2014). Hlm. 16

${ }^{8}$ Aat Syafaat, Peranan Pendidikan Agama Islam Dalam Mencegah Kenakalan Remaja(Juvenile Delinquency) (Jakarta: Rajawali Press, 2008). hlm. 14

${ }^{9}$ Nur Rahmah, "Belajar Bermakna Ausubel," Al-Khwarizmi: Jurnal Pendidikan Matematika Dan Ilmu Pengetahuan Alam, 2018, https://doi.org/10.24256/jpmipa.v1i1.54.
} 
of meaningful learning. The way of packaging the learning experience designed by the teacher was very influential on the experience for students. The way of packaging learning experiences could be through themes that were appropriate to the environment of students. Thus, the environment greatly influences how students can feel meaningful in learning. Pembelajaran yang bermakna adalah pendekatan dalam mengelola sistem pembelajaran melalui metode pembelajaran aktif menuju pembelajaran mandiri. Kemampuan untuk belajar secara mandiri adalah tujuan akhir dari pembelajaran yang bermakna. Cara mengemas pengalaman belajar yang dirancang oleh guru sangat berpengaruh pada pengalaman bagi siswa. Cara mengemas pengalaman belajar bisa melalui tema yang sesuai dengan lingkungan siswa. Dengan demikian, lingkungan sangat memengaruhi bagaimana siswa dapat merasa bermakna dalam belajar. ${ }^{10}$

David Ausubel membagi belajar menjadi dua. pertama yakni terkait dengan cara konsep-konsep yang disajikan pada siswa melalui menerima dan menemukan. kedua berkaitan dengan bagaimana peserta didik mampu menghubungkan konsep-konsep tersebut pada struktur kognitif yang telah dimiliki. Struktur kognitif adalah keadaan yang sebenarnya, konsep generalisasi yang telah di pelajari dan diingat oleh siswa. ${ }^{11}$ Itskarisma dan Mawardi mengutip pendapat Yogihati bahwa belajar bermakna adalah "was an approach in managing the learning system through active learning methods towards independent learning. The ability to learn independently was the ultimate goal of meaningful learning. The way of packaging the learning experience designed by the teacher was very influential on the experience for students. The way of packaging learning experiences could be through themes that were appropriate to the environment of students. Thus, the environment greatly influences how students can feel meaningful in learning. Pembelajaran yang bermakna adalah pendekatan dalam mengelola sistem pembelajaran melalui metode pembelajaran aktif menuju pembelajaran mandiri. Kemampuan untuk belajar secara mandiri adalah tujuan akhir dari pembelajaran yang bermakna. Cara mengemas pengalaman belajar yang dirancang oleh guru sangat berpengaruh pada pengalaman bagi siswa. Cara mengemas pengalaman belajar bisa melalui tema yang sesuai dengan lingkungan siswa. Dengan demikian, lingkungan sangat

10 Itsna Kharisma, "Implementation of an Environmental-Based Alternative Integrative Thematic Model to Increase Meaningfulness and Learning Outcome" 51, no. 3 (n.d.): $154-62$.

${ }^{11}$ Dahar, Teori-Teori Belajar Dan Pembelajaran. hlm. 94. 
memengaruhi bagaimana siswa dapat merasa bermakna dalam belajar. ${ }^{12}$ Belsasar sihombing dan Chista Sinaga mengungkapkan bahwa pebelajaran dengan teori Ausubel dapat meningkatkan aktivitas siswa sehingga akan mambantu guru dalam mencapai dari tujuan mata pelajaran yang diajarkan. ${ }^{13}$ Penelitian mengenai belajar bermakna juga dilakukan oleh Fitri Ratna Sari hasil penelitian menunjukkan bahwa penerapan teori belajar bermaka pada mata pelajaran matematika dapat meningktkan prestasi dan komunikasi matematika siswa sebesar 75\%. Hal ini membuktikan bahwa penerapan belajar bermakna dapat meningkatkan prestasi dan komukasi matematika siswa. ${ }^{14}$ penelitian yang sama juga dilakukan oleh Ariyanto hasil penelitian menunjukkan bahwa pembelajaran yang dilakukan dikelas lebih efektif dan efisien. Pelajaran matematika tidak dapat dilakukan dengan tidak selalu menemukan namun dapat juga dengan cara kebermaknaan. $^{15}$

Dari penelitian yang dilakukan sebelumnya sebagian besar pembelajaran bermakna dilakukan pada mata pelajaran umum. Pembelajaran bermakna jarang digunakan pada mata pelajara Pendidikan Agama Islam. Berdasarkan hasil wawancara dengan guru dan Kepala sekolah di Sekolah Dasar Islam Terpadu Lukman Hakim mengatkan bahwa Sekolah Dasar Islam Terpadu Lukman Hakim menerapkan belajar bermakna sebagai model pembelajaran dalam kegiatan pembelajaran hal ini dikarenakan pembelajaran bermakna sesuai dengan kurikulum yang di terapkan oleh sekolah yakni perpaduan antara kurikulum khas sekolah yakni kurikuluk Pendidikan Holistik Integratif (PHI) yang menekankan pada proses belajar dengan meberikan pengalam secara lagsung kepada siswa dengan konsep-konsep islami serta menerapkan Kurikulum 2013. ${ }^{16}$

Berdasarkan permasalah yang telah diungkapkan sebelumnay peneliti tertarik untuk melakukan penelitian pelaksanaan pembelajaran bermakna di Sekolah Dasar Islam Terpadu Lukman Hakim.

${ }^{12}$ Kharisma, "Implementation of an Environmental-Based Alternative Integrative Thematic Model to Increase Meaningfulness and Learning Outcome."

13 Christa V.Sinaga Belsasar Sihombing, "Penerapan Teori Ausubel Dengan Menggunakan Metode Inkuiri Pada Matakuliah Kalkulus," Jurnal Pendidikan Matematika Dan Terapan 1, no. 3 (2015): 102-12.

${ }^{14}$ Fitri Ratna Sari, "Program Studi Pendidikan Matematika Fakultas Keguruan Dan Ilmu Pendidikan Universitas Muhammadiyah Purworejo 2017,” 2017, 200.

${ }^{15}$ Ariyanto, "Penerapan Teori Ausubel Pada Pembelajaran Pokok Bahasan Pertidaksamaan Kuadratdi SMU," 2012, 55-64. Lukma Hakim," n.d.

16 Khairunnisa, "Wawancara Belajar Bermakna Sekolah Dasar Islam Terpadi 
Penelitian ini menggunakan pendekatan kualitatif dengan jenis penelitian deskriptif memberikan gambaran, merinci, dan menganalisa data pada permasalahan yang terjadi saat ini serta memusatkan pada pemecahan masalah. dengan teknik pengumpulan data meliputi wawancara kepada guru, kepala sekolah dan siswa, observasi roses pmebelajaran di dalam kelas, dan pengumpulan dokumentasi baik melalui foro, video, cacatan-catan maupun dokumen tertulis lainnya. Analisis Data yang digunakan dalam penelitian ini peneliti menggunakan analisis model Miles dan Huberman yakni didalamnya pengolahan datanya reduksi data, data display, kesimpulan. ${ }^{17}$

\section{Pembahasan}

\section{A. Konsep Belajar Bermakna David Ausubel}

Belajar bermakna yang dicetuskan oleh David Ausubel merupakan suau proses dikaitkannya informasi-informasi yang baru dengan konsep-konsep yang relevan dalam struktur kognitif seseorang. ${ }^{18}$ Belajar bermakna adalah pembelajaran dimana seseorang dapat menghubungkan ilmu-ilmu baru yang diperolehnya dengan ilmu-ilmu yang telah ia peroleh sebelumnya. Hasil dari kebermaknaan belajar tersebut dapat dilihat dengan adanya keterkaitan antara teori-teori, fakta-fakta, atau keadaan baru yang sesuai didalam kerangka kognitif peserta didik. Pembelajaran bukan hanya dengan menghafal materi-materi pelajaran atau peristiwa-peristiwa yang terjadi, namun belajar merupakan kegiatan yang didalamnya menghubungkan seluruh konsep yang diajarkan sehingga peserta didik tidak akan mudah lupa dan agar pembelajaran terlaksana dengan mudah. ${ }^{19}$ Menurut Suparno belajar bermakna dilakukan dengan keterkitan antara materi yang telah dipelajar dengan materi yang akan di pelajari, lebih dahulu memberikan ide atau gagasan dimulai dari yang paling global kemudian berlanjut pada hal-hal yang eksklusif atau lebih terurai, menunjukkan persamaan dan perbedaan antara materi baru dengan materi lama, dan berusaha agar gagasan yang telah ada dapat dikuasai secara keseluruhan sebelum gagasan

17 Lexy J. Moleong, Metodologi Penelitan Kualitatif (Bandung: Remaja Rosdakarya, 2012). hlm. 307.

${ }^{18}$ Tarmidzi, "Belajar Bermakna ( Meaningful Learning ) Ausubel Menggunakan Model Pembelajaran Dan Evaluasi Peta Konsep ( Concept Mapping ) Untuk Meningkatkan Kemampuan Pemahaman Konsep Mahasiswa Calon Guru," Caruban, Jurnal Ilmiah Pendidikan Dasar 1, no. 2 (2018): 131-39.

19 Mustofa, Belajar Dan Pembelajaran: Pengembangan Wacana Dan Praktik Pembelajaran Dalam Pembagunan Nasional. Hlm. 102 
yang baru disampaikan. ${ }^{20}$ Menurut Agra belajar bermakna adalah salah satu srategi belajar yang menjanjikan dalam keadan pengajaran formal, yang terdiri dari interaksi pengetahuan yang baru dengan pengetahuan yang telah dimiliki yang relevan (subsumption). Dengan demikian, dari interaksi yang berurutan, sub-bagian yang diberikan secara progresif memperoleh makna baru, menjadi lebih kaya, lebih halus, lebih berbeda, dan mampu berfungsi sebagai jangkar untuk pembelajaran baru yang bermakna. Titik refleksi utama dalam Teori belejar bermakna yakni dari semua faktor yang mempengaruhi pembelajaran hal utama yang penting adalah pengetahuan yang dimiliki siswa sebelumnya yang menjadi dasar atau pondasi yang disebut sebagai titik awal. ${ }^{21}$ Ausubel dan Novak menambahkan bahwa bagi seorang guru dalam mengajar penting untuk tahu bagaimana peserta didik dalam belajar. Jika seorang guru mengajar dengan cara menghubungkan dan mengaitkan materi maka sebgian besar dari mereka akan belajar dengan benar. Jika guru tidak dapat mengaitkan maka siswa akan mengalami kesulitan dalam belajar. ${ }^{22}$

Belajar bermakan menekankan adanya hubungan antara meteri yang baru dengan materi sebelumnya. Karena hubungan anatar materi merupkan kunci siswa akan belajar dengan baik. Materi-matri tersebut diuraikan dan kemudian dipersentasikan dengan baik dan tetap kepada siswa. Dengan ini diharapkan akan mempengaruhi pengaturan kemajuan belajar siswa. Dimana didalamnya juga ada advance organizer yang merupakan bahan pembelajaran atau informasi umum yang mengcover semua isi perjalanan yang akan diajarkan kepada kepada peserta didik. ${ }^{23}$

Lebih Jelasnya pada belajar bermakna ini dalam belajar pada tingkat pertama, pada siswa informasi dikomunikaskan dalam bentuk belajar penerimaan, siswa harus dilatih untuk menemukan sendiri sebagian dari materi

${ }^{20}$ Pembelajaran Bermakna and Hasil Belajar, "Pengaruh Penerapan Pembelajaran Bermakna (Meaningfull Learning) Pada Pembelajaran Tematik IPS Terpadu Terhadap Hasil Belajar Siswa Kelas III Di MI Ahliyah IV Palembang," JIP: Jurnal Ilmiah PGMI 2, no. 1 (2017): 19-28.

${ }^{21}$ Glenda Agra et al., "Analysis of the Concept of Meaningful Learning in Light of the Ausubel's Theory," Revista Brasileira de Enfermagem 72, no. 1 (2019): 248-55, https://doi.org/10.1590/0034-7167-2017-0691.

22 Antoni Ballester Vallori, "Meaningful Learning in Practice," Journal of Education and Human Development 3, no. 4 (2014): 199-209, https://doi.org/10.15640/jehd.v3n4a18.

${ }^{23}$ Evaline Siregar dan Hartini Nara, Teori Belajar Dan Pembelajaran (Bogor: Ghalia Indonesia, 2014). hlm 33. 
atau keseluruhan materi yang diajarkan. Selanjutnya tingkat kedua, siswa harus meghubungkan informasi itu pada pengetahuan (baik berupa konsep atau lainnya) yang telah dimiliki dari pembelejaran yan telah dilakukan sebelumnya, berikut inilah terjadi pembelajaran bermakna. ${ }^{24}$

Hasil dari pembelajaran teori Ausubel ini adalah suatu proses pembelajaran yang setelah proses pembelajarannya akan mendatangkan kognitif. ${ }^{25}$ Oleh karena itu kognitif dan materi merupakan hal yang penting dalam pembelajaran bermakna. ${ }^{26}$ Guru harus menggali konsep-konsep yang ada pada siswa sehingga dapat dipadukan dengan konsep-konsep yang akan dipelajari hal ini harus dilakukan agar terjadi pembelajaran bermakan pada siswa. Sehingga anak akan mendapatkan pengalaman langsung dari pembelajaran yang dilakukan dan anak dapat menggunakan banyak alat indranya dalam belajar. Siswa tidak hanya mendengar atau sekedar memperhatikan orang yang ada didepan atau guru yang menjelaskan materi pelajaran.

Menurut David Ausubel pembelajaran bermakna dapat terlaksana dengan memenuhi prinsip-prinsip yakni (1) Advance Organizer ata yang di sebut dengan pengaturan awal merupakan materi-materi yang dijadikan sebagai sebagai bahan untuk mengaikan anatar materi lama dengan materi baru yang memiliki makna lebih tinggi dari materi sebelumnya. (2) Defrensiasi Progresif, dalam belajar bermkana perlu adanya pengembangan materi-materi, dimana materi yang umum di sampaikan kepada siswa terlebih dahulu kemudian dilanjutkan dnegan pennyampaian materi-materi ynag sifatnya khusus. (3) Belajar Subordinat, konsep belajar dapat dilakukan jika pada materi yang akan dipelajari dengan belajar bermakan juga telah dipelajari pada materi-materi sebelumnya sehingga siswa telah memiliki pengetahua dari pelajaran sebelumnya. (4) Penyesuaian Integratif, dalam hal ini konsep pembelajarn disusun sehingga akan tercipta susunan pengetahuan secra bertingkat. ${ }^{27}$

${ }^{24}$ Nara.

25 Judiann McNulty, “Peningkatan Ativitas Siswa Pembelajaran Matematika Dengan Penerapan Teori Belajar Bermakna David Ausubel Di Kelas. (2013): 37-39.

${ }^{26}$ Hery Saputra, "Peningkatan Daya Serap Siswa Dalam Pembelajaran Matematika Dengan Penerapan Teori Belajar Bermakna David Ausubel," Jurnal Penelitian Pendidikan MIPA 1, no. 1 (2016): 21-26.

${ }^{27}$ Ahmad,“BelajarBermakna,”,http://cepiriyana.staf.upi.edu/files/2016/02/BELAJA R-BERMAKNA.pdf. 
Kebermaknaan kegiatan pembelajaran ditentukan oleh cara kegiatan belajar. Cara belajar yang terdapat dalam belajar bermakan, yaitu: ${ }^{28}$

a. Cara belajar dengan menerima. Kegitan pembelajaran lebih diditekankan dalam belajar cara memperhatikan, mengamati, mendengar kemudian dilanjutkan dengan mengkaji.

b. Cara belajar penemuan yang terpimpin. Siswa dalam belajar melakukan sendiri penarian terhadap konsep-konsep pengetahuan yang dibantu dengan bantuan yang dilakukan oleh seorang guruberdasarkan prinsip dan prosedur yag telah ada.

c. Belajar yang dilakukan dengan melakukan penemuan sendiri yakni peserta didik harus mencari pengetahuan sendiri dan tidak mendapat bantuan dari gurunya.

Dalam pembelajaran berakna terdapat prinsip-prinsip bermakna yakni (1) Advance Organizer atau yang disebut dengan pengaturan awal merupakan materimateri yang dijadikan sebagai sebagai bahan untuk mengaitkan anatara materi lama dengan materi baru yang memiliki makna lebih tinggi dari materi sebelumnya. (2) Defrensiasi Progresif, dalam belajar bermaknaa perlu adanya pengembangan materi-materi, dimana materi yang umum di sampaikan kepada siswa terlebih dahulu kemudian dilanjutkan dnegan pennyampaian materi-materi ynag sifatnya khusus. (3) Belajar Subordinat, konsep belajar dapat dilakukan jika pada materi yang akan dipelajari dengan belajar bermakan juga telah dipelajari pada materi-materi sebelumnya sehingga siswa telah memiliki pengetahua dari pelajaran sebelumnya. (4) Penyesuaian Integratif, dalam hal ini konsep pembelajarn disusun sehingga akan tercipta susunan pengetahuan secara bertingkat. $^{29}$

Selain memperhatikan prinsip-prinsip dalam belajar bermakan berikut adalah langkah-langah yang harus di perhatikan perhatikan agar tujuan dari pembelajaran bermakna dapat tercapai. Langkah-lngkah dalam proses pelaksanaan belajar bermakna adalah sebagai berikut: ${ }^{30}$

28 Donas Ahmad Najib , Pengaruh Penerapan Pembelajaran Bermakna (Meaningfull Learning) Pada Pembelajaran Tematik IPS Terpadu Terhadap Hasil Belajar Siswa Kelas III di MI Ahliyah IV Palembang. Dalam urnal Ilmiah PGMI. Volume 2, Nomor 1. (Palembang : UIN Raden Fatah, 2016)

${ }^{29}$ Ahmad,BelajarBermakna, http://cepiriyana.staf.upi.edu/files/2016/02/BELAJARBERMAKNA.pdf. Diakses pada 9/11.2019. pukul 08.58 WIB.

${ }^{30}$ Nur Rahmah, "Belajar Bermakna Ausubel," L-Khwarizmi: Jurnal Pendidikan Matematika Dan Ilmu Pengetahuan Alam, 2018, https://doi.org/10.24256/jpmipa.v1i1.54. 
1. Guru haruus mentujuan Menentkan Tujuan dari proses Pembelajaran.

2. Guru Melakukan identifikasi karakteristik siswa (kemampuan yan telah dimiliki, gaya belajar, motivasi belajar dan lain-lain)

3. Memilah dan memilih materi pembelajaran yang sesuai dengan karakteristik siswa dan membuat dalam bentuk konsep-konsep utama atau konsep inti.

4. Menentukan materi ke dalam topik-topik dan menyampaikannya dalam bentuk advance organizer yang selanjutnya dipelajari oleh siswa.

5. Mempelajari konsep-konsep inti tersebut, dan menerepkannya dalam bentuk nyata/konkret.

6. Melakukan penilaian pada proses pembelajaran dan hasil belajar dan hasil belajar siswa.

Menurut Ausubel dan juga Novak (1977), ada tiga kelebihan dari penggunaan teori belajar bermakna, Yakni: (1). Informasi yang dipelajari siwa secara bermakna akan lebih lama diingat, (2). Informasi yang tersubsumsi akan mempengaruhi peningkatan deferensiasi dari subsume subsume, sehingga akan memudahkan proses belajar pada materi selanjutnya yang memiliki kemiripan, (3). Informasi-informasi yang telah dipelajari kemudian yang dilupakan sesudah subsumsi akan mempermudah belajar hal-hal yang mirip meskipun telah lupa. ${ }^{31}$

\section{B. Pelaksanaan Pembelajaran dengan konsep Teori Belajar Bermakna David Ausubel}

Penelitian ini dilakukan di Sekolah Dasar Islam Terpadu Lukman Hakim dalam pembelajaran Pendidikan Agama Islami. Peneliti melakukan penelitian dengan wawancara, melihat dokumen dan observasi langsung kedalam kelas mengikuti pembelajaran yang dilakukan oleh guru Pendidkran Agama Islam. Hasil penelitian menunjukkan bahwa belajar bermakna telah dilaksanakan di Sekolah Dasar Islam Terpadu Lukman Hakim. Hal ini berdsarkan wawancara yang dilakukan dengan guru Pendidikan Agama Islam bahwa belajar bermakna merupakan pembelajaran yang telah lama dilakukan dan sesuai dengan kurikulum di Sekolah Dasar Islam Terpadu Lukman Hakim yakni perpaduan antara kurikulum 2013 dan kurikulum Pendidikan Holistik Integratif (PHI).

31 Joko Sulianto, "Teori Belajar Kognitif David Ausubel"Belajar Bermakna”, Zoltan P Dienes "Belajar Permainan", Van Heille"Pengajaran Geometri"," PGSD IKIP PGRI Semarang, 2019, 1-15. 
Hal ini juga diperkuat dengan keterangan siswa yang mengatakan bahwa siswa belajar dengan menghubungkan antara pengetahuan yang telah dimiliki dengan pengetahuann yang akan dipelajari.

Untuk melihat apakah pelaksanaan pembelajaran bermakna di Sekolah Dasar Islam Terpadu Lukman Hakim sudah sesuai pembelajaran bermakna David Ausubel makan peneliti melakukan observasi dan wawancara sehingga diperoleh hasil pelaksanakan bedasarkan prinsipsip pembelajaran bermakna yakni dengan Prinsip pertama adalah prinsip pengaturan awal prinsip ini mengarahkan siswa pada materi yang akan dipelajari dan mengingatkan siswa pada materi yang yang telah di pelajari sebelumnya. ${ }^{32}$ Pada pembelajaran yang dilakukan di Sekolah Dasar Islam Terpadu Lukman Hakim guru telah melakukan prinsip ini dimana berdarkan observasi peneliti menemukan guru menghubungkan materi pelajaran bab ke lima "Keteladanan Rasulullah" dengan materi yang pernah dipelajari sebelumnya. Pada pembelajaran dikelas guru menghubungkan dengan materi "Mari Mengenal Rasul rasul Allah, Rasulul Allah Idolaku" pada kelas V dan "Nabi Muhammad saw Panutanku" pada kelas III. Prinsip kedua adalah Defrensiasi Progresif, pada pelaksanaanya guru menyusun pembelajaran dari yang umum kemudian ke khusus agar dapat dengan mudah dipelajari dan dipahami siswa. Dalam RPP dan materi yang telah disusun oleh guru, guru Pendidikan Agama Islam telah menyusun materi pembelajara dimulai dari konsep yang umum kemudian ke konsep yang khusus. Selanjutnya ada proses pembelajaran pada materi "Mengenal Rasul-Rasul Allah, Rasulullah idolaku pada kelas V merupakan konsep yang secara luas kemudian mengerucut menjadi keteladanan rasulullah pada pembahasan kelima ini guru mengurakan konsep pada kelas V. Prinsip yang ketiga, yakni belajar superordinat. Belajar ini dapat terjadi apabila materi-materi yang diajarakan sebelumnya merupakan materi-materi yang besar cakupannya atau global. ${ }^{33}$ Pada materi kelas sebelumya siswa diperkenalkan dengan materi tentang nabi Muhammad saw secara umum dan materi pada saat ini yang dijarkan adalah keteladanan dari nabi Muhmmad saw yang merupakan merupakan kelanjutan dari materi global yang materi yag diajarkan sebelumnya. Prinsip yang yang keempat, yakni keempat adalah penyesuaian integrated yang terdiri dari beberapa langkah. Langkah tersebut

\footnotetext{
${ }^{32}$ Ahmad, "Belajar Bermakna."

${ }^{33}$ Ahmad. Belajar Bermakna
} 
terbagi menjadi dua yakni tahap perencanaan dan tahap pelaksanaan dalam proses pembeljaran.

Berdasarkan hasil wawancara dan Observasi tahap pertama dalam prinsip keempat ini adalah fase perencanaan. Berdasarakan hasil wawancara sebelum melakukan pembelajaran guru terlebih dahulu membuat tujuan pembelajaran yakni tujuan pembelajarannya adalah memahami konsep "keteladanan rasulullah" dan dapat memperaktekkanya dalam kehidupan sehari-hari.(2) Menganalisis pengetahuan peserta didik pada materi yang telah dipelajarai sebelumnya, pengetahuan yang dimiliki oleh siswa yakin : (a) mengenal rasul rasul allah, (b) rasulullah idolaku (c) Nabi Muhammad saw panutanku. (3) Membuat struktur konsep mengenai materi yang akan diajarkan kepada siswa. Berdasarkan wawancara hal ini dilakukan untuk memudahkan peserta didik dalam memahimi dan agar peserat didik dapat menghubungkan pengetahuan baik pengetahuan yang telah dipelajari dan pengetahuan yang akan dipelajari. (4). Memformulasikan Advance Organizer, untuk mengajarkan pokok bahasan "Keteladanan Rasulullah", meliputi (a) "Mari Mengenal Rasul rasul Allah, (b) Rasulul Allah Idolaku” (c) Nabi Muhammad saw Panutanku. Istilah advance organizer artinya kesadaran siswa terhadap strukrut pengetahuan yang sedang dimilikinya sehingga informasi baru dapat dikaitkan dengan pengetahuan sebelumnya yang disebut juga sebagai keragka pengait.

Setalah fase persiapan maka tahap selanjutnya adalah Fase Pelaksanaan. Fase pelaksanaan akan di jelaskan berikut ini.

Pelaksanaan pembelajaran bermakna.

Urian Kegiatan

Guru menanayakan keembali tentang mengenal rasul rasul allah, rasulul Allah idolaku pada kelas V dan Nabi Muhammad saw panutanku pada kelas III pada bab tiga. Guru mengingakan kebali mengenal rasul rasul allah, rasulul Allah idolaku pada kelas V dan Nabi Muhammad saw panutanku pada kelas III
Prinsip Yang Digunakan

Advance Organizer

Advance Organizer 
174 | Belajea: Jurnal Pendidikan Islam, Vol. 5, No. 01, 2020

pada bab tiga.

Guru memberi problem

mengenai hubungan materi

mengenal rasul rasul allah,

rasulul Allah idolaku, Nabi

Muhammad saw panutanku.

Guru melanjutkan

keteladanan Rasulullah

Difrensiasi Progresif

Dengan media video guru

menjelaskan materi

keteladanan rasulullah

Dengan arahan guru siswa

diminta untuk meneyelesaikan

persoalan menganai

keteladanan rasulullah

Advance Organizer

Diferensiasi Progresif

Rekonsiliasi Integratif

Hal diatas merupakan pelaksanaan berdasarkan prinsip pembelajaran bermakna di Sekolah Dasar Islam Terpadu Lukman Hakim. Berdasarkan tabel diatas menunjukkan bahwa pembelajaran tersebut sudah berlangsung dengan baik yakni guru melakukan Advance Organizer karena menurut Ausubel peserta didik akan belajar dengan baik jika apa yang disebut pengantar kemajuan (Advance Organizers) didefinisikan dan dipersentasikan dengan baik dan tepat kepada siswa. ${ }^{34}$ Sehingga siswa sudah tau dasar dari apa materi yang akan ia pelejari selanjutnta. namun akan lebih baik jika pada tahap akhir dilakukan konsolidasi atau pemantapan terhadap materi agar benar-benar tuntas pembelajaran yang berlangsung. Kemudian dilakuka kembali Rekonsiliasi Integratif akhir kembali dari keseluruhan proses pembelajaran.

Berdasarkan hasil wawancara yang dilakukan kepada siswa, mereka merasa bahwa pembelajaran dengan metode ini mempermudah siswa karena siswa belajar dengan mengingat materi yang telah lalu dan menghubungkan dengan materi yang akan dipelajari sehingga menyenangkan. Selain itu juga berdasarkan wawancara dengan guru terdapat peningkatan prestasi belajar setelah hampir tiga tahun diterpakannya pembelajaran ini salah satunya adalah

${ }^{34}$ Hamzah B. Uno, Orientasi Baru Dalam Psikologi Pembelajaran (Jakarta: Bumi Aksara, 2016). hlm 56. 
siswa Sekolah Dasar Islam Terpadu Lukman Hakim masuk dalam peringkat 5 besar dalam ujian nasional pada nilai Pendidikan Agama Islam sekecamatan Banguntapan. ${ }^{35}$

Dari pembelajaran guru menyatakan bahwa secara keseluruhan jika pembelajaran bermakna dilaksankan dengan baik dan benar kan memberikan efek Siswa akan memiliki daya ingat yang lama terhadap materi yang dipelajarinya jika dibandingakn dengan menggunakan belajar dengan hafalan. Hal ini di karena setiap pengetahuan atau konsep yang di berikan kepada siswa dikaitkan dengan struktuk pengetahuan yang teleh dimiliki oleh siswa tersebut. Kemudian Proses belajar dan mengajar yang dilakukan di sekolah akan terlaksana dengan efektif dan lebih efisien. Dengan adanya teori ini guru akan terbiasa menysusun materi pembelajaran secara terkonsep.

\section{Faktor-Faktor Yang mempengaruhi pelaksanaan Pelaksanaan Teori Belajar Bermakna}

1. Faktor Pendukung Pelaksanaan Teori Belajar Bermakna

Dalam pelaksanaan sebuah metode belajar pasti menjumpai faktor yang menjadi pendukung dan faktor yan menjadi penghambat. Dalam pembelajaran yang dilaksanakan di Sekolah Dasar Islam Terpadu Lukman Hakim berdasarkan hasil pengamatan dan wawancara yang dilakukan yang menjadi faktor pengahambat dan pendukungnya adalah sebagai berikut:

Faktor pendudukung pembelajaran bermakna adalah (1) kurikulum yang diterapkan di sekolah adalah Kurikulum 2013 yang di padukan dengan kurikulum Pendidikan Holistik Integratif (PHI) yang salah satu metode pembelajarannya harus memberikan pengalaman secara langsung kepada siswa, sehingga siswa tidak hanya belajar dengan memperhatikan guru namun siswa mempraktikkan langsung sehingga siswa memiliki pengalaaman. ${ }^{36}$ (2) Guru memiliki kemampuan pedagogik yang baik sehingga dapat menyampaikan materi pembelajaran dengan pembelajarn bermakna. (3) Sarana dan Prasana yang mendukung untuk guru dapat menerapkan pembelajaran bermakna bagi peserta didik.

\section{Faktor Penghambat Pelaksanaan Teori Belajar Bermakna}

\footnotetext{
${ }^{35}$ Wawancara Guru Pendidikan Agama Islam

${ }^{36}$ Wawancara Guru Pendidikan Agama Islam
} 
Tidak dapat dipungkiri bahwa dalam suatu proses semua dapat berjalan dengan baik terutama dalam proses belajar mengajar yan melibatkan banyak orang tidak hannya guru namun juga dengan para peserta didik. Hambatan yang terdapat pada pembelajarn bermakna ini terutaman berasal dari peseta didik. Tidak semua peserta didik memiliki kemampuan dan semangat dan kemampuan yang sama sehingga tidak semua siswa dapat aktif dalam pembelajaran dan tidak semua siswa memiliki daya ingat yang sama salah satu hal yang penting dalam terhadap materi yang telah lalu sehingga guru sehingga harus bekerja keras untuk dapat membuat siswa ini dapat mengikuti pembelajaran.

\section{Penutup}

Berdasarkan teori serta kerankan konsep yang telah di jelakan di atas maka dapat disimpulkan sebagai berikut;

1. Belajar bermakna David Ausubel merupkan pemebalajaran yang yangdilakukan dengan menguhungkan antara pengetahuan pada pembelajaran yang telah dilalui dengan materi-materi yanga akan disampaikan pada materi selanjutnya dan seorang guru di tuntut untuk dapat menysun materi sedemikian rupa sehingga pembelajar ini dapat benar-berakmakna bagi siswa. Dalam pembelajaran ini peserta didik dapat menggunakan lebih bnayak indranya tidak hanay mendengar atau melihat saja namun siswa juga melakukan.

2. Pelaksanaan belajar bermakna yang dilakukan Sekolah asar Islam Terpadu Lukman Hakim adal pembelajarn bermakna yang di kombinasikan dengan kurikulum Pendidikan Holistik Integratif denhan menggunkan konsep holitik yang dalam pembelajaarannay mengintegrasikan anatara mata dengan konsep-konsep islami. Pelaksanaan pembelajaran bermakna pada mata pelajaran penidikan aagama islam diawali dengan prinsip pengaturan awal siswa dimbing ke materi yanga akan d pelajari dengan mengingat kembali pada konsepkonsep yang telah dipelajari. Pada pembelajaran yang dilakukan di Sekolah Dasar Islam Terpadu Lukman Hakim guru telah melakukan prinsip ini dimana guru menghubungkan materi pada bab ke lima dengan materi yang pernah dipelajari sebelumnya yakni materi "keteladanan rasulullah" Guru menghubungkan dengan materi mari mengenal rasul rasul allah, rasulul Allah idolaku pada kelas $\mathrm{V}$ dan Nabi 
Muhammad saw panutanku pada kelas III. Prinsip yang kedua yakni belajar superordinat, belajar ini dapat terjadi apabila materimateri yang sebelumya di pelajari merupakan materi yang memiliki cakupan besar atau umum. Pada materi mengenal rasul-rasul allah, Rasulul Allah idolaku pada kelas $\mathrm{V}$ merupakan konsep yang secara luas kemudian mengerucut menjadi keteladanan rasullah pada pembahasan kelima ini guru mengurakain konsep pada kelas V. Prinsip yang yang terakhir yakni ketiga adalah penyesuaian integrated yang terdiri dari beberapa tahap yaitu tahap perencanaan dan tahap pelaksanaan. tahap pelaksanaan dan tahap perencanaan sudah baik namun guru tidak mengulang kembali fase diferensia progresif. Karena mengulang fase diferensia progresi juga pentig untuk kembali memastikan bahwa pembelajaran tersebut berhasil 
178 | Belajea: Jurnal Pendidikan Islam, Vol. 5, No. 01, 2020

\section{Bibliografy}

Agra, Glenda, Nilton Soares Formiga, Patrícia Simplício de Oliveira, Marta Miriam Lopes Costa, Maria das Graças Melo Fernandes, and Maria Miriam Lima da Nóbrega. "Analysis of the Concept of Meaningful Learning in Light of the Ausubel's Theory." Revista Brasileira de Enfermagem 72, no. 1 (2019): 248-55. https://doi.org/10.1590/0034-7167-2017-0691.

Ahmad. "Belajar Bermakna," / cepiriyana.staf.upi.edu/files/2016/02/BELAJARBERMAKNA.pdf.

Ariyanto. "Penerapan Teori Ausubel Pada Pembelajaran Pokok Bahasan Pertidaksamaan Kuadratdi SMU,” 2012.

Belsasar Sihombing, Christa V.Sinaga. "Penerapan Teori Ausubel Dengan Menggunakan Metode Inkuiri Pada Matakuliah Kalkulus." Jurnal Pendidikan Matematika Dan Terapan 1, no. 3 (2015).

Bermakna, Pembelajaran, and Hasil Belajar. "Pengaruh Penerapan Pembelajaran Bermakna (Meaningfull Learning) Pada Pembelajaran Tematik IPS Terpadu Terhadap Hasil Belajar Siswa Kelas III Di MI Ahliyah IV Palembang." JIP: Jurnal Ilmiah PGMI 2, no. 1 (2017).

Dahar, Ratna Wilis. Teori-Teori Belajar Dan Pembelajaran. Bandung: Erlangga, 2006.

I Pt. Fira Kumartha, Md. Putra, I Wyn Sujana. "Bernuansa Lingkungan Alam Terhadap Hasil Belajar Ips Siswa Kelas Iv Sd Gugus 4 Selemadeg Timur Tabanan." Portal Garuda, 2013.

J. Moleong, Lexy. Metodologi Penelitan Kualitatif. Bandung: Remaja Rosdakarya, 2012.

Khairunnisa. "Wawancara Belajar Bermakna Sekolah Dasar Islam Terpadi Lukma Hakim," n.d. 
Kharisma, Itsna. "Implementation of an Environmental-Based Alternative Integrative Thematic Model to Increase Meaningfulness and Learning Outcome" 51, no. 3 .

Majid, Abdul. Belajar Dan Pembelajaran :Pendidikan Agama Islam. Bandung: Remaja Rosdakarya, 2014.

Mustofa, Muhammad Thabrani dan Ali. Belajar Dan Pembelajaran: Pengembangan Wacana Dan Praktik Pembelajaran Dalam Pembagunan Nasional. Yogyakarta: Ar-Ruzz Media, 2011.

Nara, Evaline Siregar dan Hartini. Teori Belajar Dan Pembelajaran. Bogor: Ghalia Indonesia, 2014.

Rahmah, Nur. "Belajar Bermakna Ausubel." Al-Khwarizmi: Jurnal Pendidikan Matematika Dan Ilmu Pengetabuan Alam, 2018.

_. "Belajar Bermakna Ausubel." L-Khwarizmi: Jurnal Pendidikan Matematika Dan Ilmu Pengetabuan Alam, 2018.

Saputra, Hery. "Peningkatan Daya Serap Siswa Dalam Pembelajaran Matematika Dengan Penerapan Teori Belajar Bermakna David Ausubel." Jurnal Penelitian Pendidikan MIPA 1, no. 1 (2016)

Sari, Fitri Ratna. "Program Studi Pendidikan Matematika Fakultas Keguruan Dan Ilmu Pendidikan Universitas Muhammadiyah Purworejo 2017," 2017, 200.

Shoffa, Shoffan. "Penerapan Strategi Meaningful Learning Dalam Meningkatkan Hasil Belajar Mahasiswa Pendidikan Matematika UM Surabaya Pada Mata Kuliah Pengantar Pendidikan.” MUST: Journal of Mathematics Education, Science and Technology, 2016.

Sulianto, Joko. "Teori Belajar Kognitif David Ausubel"Belajar Bermakna", Zoltan P Dienes "Belajar Permainan", Van Heille"Pengajaran Geometri"., PGSD IKIP PGRI Semarang, 2019. 
180 | Belajea: Jurnal Pendidikan Islam, Vol. 5, No. 01, 2020

Syafaat, Aat. Peranan Pendidikan Agama Islam Dalam Mencegah Kenakalan Remaja(Juvenile Delinquency). Jakarta: Rajawali Press, 2008.

Tarmidzi. "Belajar Bermakna ( Meaningful Learning) Ausubel Menggunakan Model Pembelajaran Dan Evaluasi Peta Konsep (Concept Mapping ) Untuk Meningkatkan Kemampuan Pemahaman Konsep Mahasiswa Calon Guru." Caruban, Jurnal Ilmiah Pendidikan Dasar 1, no. 2 (2018).

Uno, Hamzah B. Orientasi Baru Dalam Psikologi Pembelajaran. Jakarta: Bumi Aksara, 2016.

Vallori, Antoni Ballester. "Meaningful Learning in Practice." Journal of Education and Human Development 3, no. 4 (2014): 199-209.

Walgito, Bimo. Pengantar Psikologi Umum. Yogyakarta: ANDIOFFSET, 2004. 